\title{
General Regulations on the Right to Paid and Unpaid Leave in the Croatian Labour Law
}

\author{
Dragan ZlatoviĆ \& IVANA KARDUM GOLEŠ
}

\begin{abstract}
In this article, authors are referring to the legal framework of the regulation of the right to have leave in new Croatian labour law. The Croatian Labour Act provides for the right to paid leave and the institute of unpaid leave. Unpaid leave is the time when a worker is exempt from labour obligations and for whom the rights and obligations arising from or in connection with the employment relationship are to rest during that time, unless otherwise specified. A paid leave is the time at which a worker is exempt from labour obligations during which he/she is entitled to remuneration, as well as all other employment rights, which is considered to be time consumed at work. The issue of leave, in particular the right to paid leave, is regulated by the Labour Act and the provisions of collective agreements, labour regulations and employment contracts.
\end{abstract}

Keywords: • labour law $\bullet$ paid leave $\bullet$ unpaid leave $\bullet$ employment contract $\bullet$ collective agreement $\bullet$

Correspondence AdDress: Dragan Zlatović, PhD, Assistant Professor, Polytechnic of Sibenik, Sibenik, Croatia, e-mail: zlatovic@vus.hr. Ivana Kardum Goleš, MSc, Seniour Lecturer, Polytechnic of Sibenik, Sibenik, Croatia, e-mail: ikardum000@gmail.com. 


\section{Introduction}

The aim of this article is to present the legal framework regarding the regulation concerning the right to have leave under the new Croatian labour law. This is one of the essential social rights of workers in the European Union. The article consists of the following sections: introduction; a brief comparison of regulations; the definition and various types of leave under the Croatian labour law; issues surrounding both paid and unpaid leave; and conclusion. The right to paid leave is a particularly important principle of both EU labour and social law.

A worker's time, at the most fundamental level, can basically be divided into hours spent actually working and leisure hours. The worker is under no legal obligation to work for the employer during leisure hours. It is imperative to distinguish workers' right to leave from workers' right to leisure or as sometimes referred to in this article, rest. The purpose of workers' rest is to help restore both physical and mental strength. Both are essential to enable workers to not only perform work tasks successfully and efficiently but also to live productively and happily during rest. The purpose of the leave is to allow the employee paid or unpaid leave for work due to certain personal reasons. This article will analyse the right to leave in national legislation and will provide suggestions concerning possible legal solutions that will better regulate this critical area of the law.

\section{Brief comparison of regulations}

Unlike vacation (break, daily rest, weekly rest, rest), leave is the time when the worker is exempted from the obligation to work. Leave does not involve reimbursement or rejuvenation of physical and mental power, but is affected because of certain prescribed cases that are a prerequisite for using leave as the right or opportunity.

Pursuant to Article 31(2) of the EU Charter of Fundamental Rights (hereinafter: EU Charter) every worker has certain basic minimum legal protections including restrictions on maximum working hours, together with the right to both daily and weekly rest and to an annual period of paid leave. The EU Charter is the most reliable and definitive confirmation of the fact that the right to paid annual leave constitutes 
LEXONOMICA

a fundamental right. However, it contains no similar provisions guaranteeing workers the right to other forms of paid and unpaid leave (Bercusson, 2002: 15).

The current legal framework at both the EU and Member States' level fails to provide harmonized provisions for workers to utilize the right to leave in the same cases. For instance, there is currently no EU legislation providing for paternity leave or leave to take care of ill or dependent relatives, with the exception of absence for force majeure (Löwisch, 2003: 111).

For example, as is the case in other European countries, Spanish labour law is very comprehensive and provides significant protections for employees. ${ }^{1}$ Labour law regulates individual and collective relationships between employees and employers, the scope of which extends to other related areas such as social security, health and safety at work, special employment relationships and procedural law. Under Spanish labour law, workers may take paid time off for some of the reasons listed below with the number of days allowed prescribed by law: a) birth of a child or death, accident or serious illness or hospitalization of relations - two calendar days or four if required to travel; b) moving home - one day; c) meeting public and private obligations (jury service, appearance in court, etc.) - as long as necessary; d) performing trade union or workers' representative activities: as established by law or collective agreement, etc. In every case, the worker must inform the employer in advance and justify his or her absence in order to exercise these rights. Unpaid leave, of course, refers to time off work without pay that must be requested by the worker and may be granted at the discretion of the employer but must always be established either in an individual or collective agreement. Periods of unpaid leave are not regulated under Spanish law.

In Poland workers have the right to annual, continuous and paid holidays. Workers must not waive the right to a leave. If documented, employment periods by foreign employers for citizens of the EU or EFTA Member States are calculated against the employment period for employee benefits in Poland. Poland recognizes the following types of leaves: holidays, maternity, paternity, childcare, study, parental, and unpaid. Unpaid leave is granted at the written request of workers (the leave is not calculated against the employment period which is a basis for employee benefits). There are a number of events that trigger workers' rights to be released from the obligation to

\footnotetext{
${ }^{1}$ Royal Decree 1/1995, consolidated version, as last amended by Law 35/2010, Royal Decree Law 3/2012, Law 3/2012, Royal Decree Law 11/2013, Royal Decree Law 16/2013 and Law 22/2013.
} 
work, the most frequent including: incapacity to work due to a sickness, the need to attend medical examinations, the necessity to care for a child, and personal or family events like marriages or funerals. Should the worker be released from the obligation to work due to, for example, the worker's marriage, the birth of his or her child or the funeral of the worker's spouse, child, father, mother, step-father or step-mother, the worker has the right to be granted two days of leave. Should the worker be released from the obligation to work due to the marriage of his or her child or the death and funeral of his or her sister, brother, mother-in-law, father-in-law, grandmother, grandfather or any other person supported or directly cared for by the worker, the worker has the right to be granted one day of leave. During the leave for the abovementioned reasons, the worker has the right to the same remuneration as if he or she were at work. Workers rearing at least one child may be released from the obligation to work for 16 hours or two days during the calendar year, with the right to remuneration, up until each child in a multiple birth family reaches the age of 14 . On the other hand, workers striving to improve their professional qualifications may be (in addition to the above-mentioned study leave) released from the whole or part of the working day in order to attend obligatory classes (the workers retain the right to remuneration for the time of leave). ${ }^{2}$

In Italian labour law, by comparison, all workers are entitled to paid leave for three working days per year in the event of serious illness or death of their spouse or second-degree relative or a partner certified by the appropriate documentation to be living with them. In the event of such serious illness, the worker also may negotiate alternative working arrangements with the employer. Continuous or discontinuous leave of up to two years may be allowed for serious, documented family reasons. In such instances, however, workers are not entitled to remuneration for the leave taken and the period is not taken into consideration when calculating length of service for social security purposes. ${ }^{3}$

\footnotetext{
${ }^{2}$ Labour Code of June 26,1974. Swiatkowski, A., Termination of Employment Relationship: The Legal Situation in Poland, https:// ec.europa.eu/social/BlobServlet?docId=4633\&langId=en (10. 4. 2019).

${ }^{3}$ Act No. 300 of 20 May 1970 on Workers' Protection, also known as the Workers' Statute, as last amended by Legislative Decree 14. 9. 2015.
} 
In Slovenia, the Employment Relationship $\mathrm{Act}^{4}$ stipulates that workers are entitled to up to seven working days of paid leave per calendar year for personal reasons (own wedding, death of spouse, child or parent, serious accident). And in such instances, the worker has the right to paid absence from work for at least one whole business day. Additionally, Slovenian workers are entitled to be absent from work in the event of temporary incapacity to work due to illness or injury or in order to donate blood or to fulfil other specified obligations such as military exercises, jury service, etc. ${ }^{5}$

In Belgium, workers have the right to be absent from work for compelling reasons. Compelling reasons are deemed to be any unforeseeable events that require a worker to leave urgently, provided that the execution of the employment contract makes this possible (for example: a person living with the worker is involved in an accident, the worker's home is damaged by fire, etc.). Such leave must not, however, exceed ten working days in a calendar year. Furthermore, this leave is unpaid, unless agreed otherwise between the employer and the employee. ${ }^{6}$

For an example of a country outside of the EU, under Serbian Labour Law ${ }^{7}$ employees have the right to absences from paid work (paid leave) for up to five working days during the calendar year, in case of marriage, the birth of a child, hardship involving a close family member, and in other cases determined by general act or employment contract. Further, the employer can employ an employee to grant absence without compensation (unpaid leave). During the period of unpaid leave, employees are entitled to the rights and obligations arising from the employment relationship, if for certain rights and obligations the law, the general act and the employment contract are not otherwise defined.

Apart from the absence of force majeure, there have so far been no EU regulations which prescribe parental leave or leave to care for sick or functionally dependent family members. In the national legislations of the EU Member States, such measures either do not exist or are incomplete. Therefore, on 4th September 2019, the European Parliament adopted the Directive (EU) 2019/1158 of the European Parliament and of the Council of 20 June 2019 on work-life balance for parents and carers and repealing

\footnotetext{
${ }^{4}$ Official Gazette RS, No. 21/13, 78/13, 47/15, 33/16, 52/16, 15/17 and 22/19.

${ }^{5}$ See more at Kresal Šoltes in Belopavlovič et al., 2019: 972-974.

${ }^{6}$ Labour Act [LA], 16 March 1971, as last alended in March 2017.

${ }^{7}$ Labour Law [LL], dated 2005 as last amended in 2017 by Law No. 13/2017.
} 
Council Directive 2010/18/EU. ${ }^{8}$ The Directive aims to ensure the implementation of the principle of equality of women and men in the labour market in accordance with current trends and needs to adapt and modernize the legal framework of the EU, which helps to ensures that parents and other persons giving care are better able to harmonize business and private obligations. Apart from being based on existing rights, the Directive either introduces new rights, or partially strengthened the existing rights, and in particular we point to the newly-granted right to custody set forth in Article 6 (Carers' leave). Accordingly, the Member States will have to adopt the necessary measures to ensure that workers acting as care givers have the right to leave for at least five working days a year. This right may be conditioned upon an appropriate medical certificate outlining the health status of a member of the family of workers that requires care. This Directive also lays down a framework for Member States to help fulfil the principle of equal treatment between men and women engaged in an activity in a self-employed capacity, or contributing to the pursuit of such an activity. The Directive respects both the well-established national arrangements for leaves and flexible working arrangements and the possibility for the Member States and the social partners to determine the specific provisions thereof. Member States who already have in place more favourable provisions than those delineated in this Directive will not have to change their legislation. Member States may also decide to pass legislation that is more generous to workers than the minimum standards set out in this Directive. ${ }^{9}$

\section{Definition and types of leave in the Croatian Labour Law}

The precise definition of leave in Croatian labour law and work related doctrine was set forth by Tintic in his seminal piece from this area, which reads: “... the leave is the departure (absence) of the worker from work (from work position) at the time when he/she is obliged to be at work, with or without compensation in salary, based on and within the limits of the rules prescribed by law, and upon approval (with consent) by the authority of the employer's body in charge of such matters" (Tintić, 1972: 512).

\footnotetext{
${ }^{8}$ OJ L 188, 12. 7. 2019, p. 79-93.

${ }^{9}$ Proposal for a Directive of the European Parliament and of the Council on work-life balance for parents and carers and repealing Council Directive 2010/18/EU, https://eur-lex.europa.eu/legal-content/EN/TXT/?uri=CELEX\%3A52017PC0253.
} 
In other words, the concept of leave is reduced to two meanings (Dedić, GradaščevićSijerić, 2003: 270-271):

- the abstract ability to use a leave related to the status of a worker; and

- the subjective right of workers from employment relationship.

Leaves in Croatian labour law can be divided into paid leave and unpaid leave, with regard to the right to salary compensation, as well as other rights in work, and on the basis of work that the employee benefits from. Based on the purpose and objective of the leave, we can further divide leave on the bases of those which are approved at the worker's request (for their private or family needs); those made at the employer's initiative with the consent of the worker (for vocational education or training); and maternity and parental leave and other allowances related to children (Jelčić, 2010: 235).

General regulations usually govern issues pertaining to differences between paid and unpaid leave; the calculations of the length of leave and the length of work; the maximum length of leave; and, the procedures for requesting and approving leaves, among other things. With this general regulation, the Croatian Law also permits regulations which govern special leave arrangements, and these have priority over general regulation. ${ }^{10}$

\footnotetext{
${ }^{10}$ For example, the right to leave as a maternity allowance is prescribed by the Act on Maternity and Parental Benefits (Official Gazette, No. 85/08, 110/08, 34/11, 54/12, 152/13, 152/14 and 59/17), following the Decision of Council Directive 2010/18/EU of 8 March 2010 on the implementation of the revised Framework Agreement on parental leave concluded by BUSINESSEUROPE, UEAPME, CEEP and ETUC and on the non-application of the Directive 96/34/EC (OJ L 68, 18. 3. 2010). According to this Act, an employed or self-employed pregnant woman, or an employed or self-employed mother, is entitled to a compulsory maternity leave for an uninterrupted period of 98 days; 28 days before the expected date of birth and 70 days after the birth of the child. After the compulsory maternity leave, an employed or self-employed mother has the right to an additional maternity leave up to six months after the child's birth, which may, by her written statement, transfer to the father of the child, with his prior consent either wholly or for a limited period of time. An employed or selfemployed parent is entitled to a parental leave of eight or 30 months, depending on the number of children born and how the leave is used. An employed or self-employed parent has the right to parental leave of 8 months, for the first and second child or 30 months, for the born twins, the third and each subsequent child. The right to parental leave is normally used by both parents, each of four or 15 months. If the parental leave is used by only one parent, and according to their agreement, it is used for six months for the first and second born or 30 months for the born twins, the third and each subsequent child.
} 
The new Croatian Labour Act ${ }^{11}$ (hereinafter: ZOR) regulates the general right to leave in Articles 86 and 87, as follows:

“Article 86 [Paid leave]

(1) During the calendar year a worker is entitled to exemption from the obligation of work with reimbursement of salary (paid leave) for important personal needs, in particular concerning marriage, childbirth, severe illness or death of a close family member.

(2) A worker is entitled to leave referred to in paragraph 1 of this Article for a total amount of seven working days per year, unless otherwise regulated by a collective agreement, regulations on work order or a work contract.

(3) A close family member referred to in paragraph 1 of this Article shall be considered to be a spouse, a relative of blood in the right line and their spouses, brothers and sisters, stepchildren and foster children, children entrusted to care and upbringing or children on care outside of their own family, stepmother, stepfather, adoptive parent, and person legally obligated to support under the law, and a person who lives with a worker in extramarital union.

(4) A worker shall be entitled to a paid leave during the education or vocational training and specialization and education for the purposes of the workers 'council or trade union work, under terms, duration and compensation provided for by a collective agreement, by an agreement concluded between the workers' council and the employer or the regulations on procedure.

(5) For the purpose of acquiring employment rights or in relation to work relationship, periods of paid leave shall be regarded as periods completed at work.

(6) A blood donor shall be entitled to one free day paid on the day of blood donation, unless in the collective agreement, the agreement concluded between the workers' council and the employer or the contract of employment, is otherwise regulated.

${ }^{11}$ Official Gazette, No 93/14 and 127/17. 
LEXONOMICA
D. Zlatović \& I. Kardum Goleš: General Regulations on the Right to Paid and Unpaid
Leave in the Croatian Labour Law

Article 87 [Unpaid leave]

(1) An employer may authorize an employee on his/her request for an unpaid leave.

(2) During the unpaid leave the rights and obligations arising out of employment or in connection with the employment relationship shall be rested, unless otherwise provided by law."

According to Article 123 ZOR cancellation period runs during the paid leave unless this otherwise regulated in the collective agreement, labour regulations or labour contract.

\section{$4 \quad$ Paid leave}

Under Croatian legislation, paid leave (German bezahalter Urlaub) is the time during which a worker is exempt from labour obligations and is entitled to remuneration, as well as all other employment rights, and which is considered to be time consumed at work (Zlatović, Malenica, 2016: 236). During the calendar year, a worker is entitled to be exempt from labour obligation with paid wages (paid leave) for important personal needs, in particular concerning marriage, ${ }^{12}$ childbirth, severe illness or death of a close family member, for a total duration of seven working days a year, unless otherwise regulated by a collective agreement, labour regulations or a work contract. $^{13}$

Therefore, as the provisions of the ZOR do not provide for the lower or upper limit of the paid leave, the same can be determined in a longer or shorter period of seven working days (non-calendar), if it is prescribed by a collective agreement, labour order or work contract as an autonomous power of work law (Jug, 2010: 121). Members of the close family, according to Article 86(3) of ZOR, include spouses,

\footnotetext{
${ }^{12}$ If, for example, a person was married by a registrar at a time when he/she was not yet employed and then became employed with an employer and during that time got married to a same spouse in church matrimony, then the same person is not entitled to a paid leave because the marriage was officially concluded earlier. The right to a paid leave belongs to the worker only at the time when the event for which leave is to be made occurs but not afterwards. See questions and answers on the portal www.radno-pravo.hr.

${ }^{13}$ The ZOR contains no definition of what is considered to be a major illness for the exercise of the right to paid leave. The Ministry of Labour and Pension System has given its opinion, although extremely restrictive, that a severe disease is considered to be a disease that cannot be cured or for which there is not a remedy or an appropriate treatment, as a result of which there is the need for care for a member of a family suffering from such an illness. See Opinion of the Ministry of Labour and Pension System dated 26. 11. 2014.
} 
blood relatives in the right line and their spouses, brothers and sisters, stepchildren and foster children, children entrusted to custody and upbringing or children supported outside of their own family, stepfather and stepmother, adoptive parent, and a person entrusted by law to a worker for support, and a person who lives with a worker in an extramarital union. ${ }^{14} \mathrm{~A}$ worker is entitled to a paid leave "for important personal needs" after the worker files for such a request, and in the case of a worker's immediate family member's death, there are opinions that it is sufficient that the worker inform only the employer, and that the worker may provide the evidence of death even after the worker's return to work (Jelčić, 2010: 236).

The right to one free day of paid leave is also provided to a volunteer blood donor for the day of donating blood, unless in the collective agreement, the agreement concluded between the workers' council and the employer or the labour contract, the matter is otherwise regulated (more at Učur, 2010: 25-28). ${ }^{15}$ If this right is not resolved in one of the ways mentioned above, the worker is entitled to one free day for any blood donation. ${ }^{16}$

\footnotetext{
${ }^{14}$ See Decision of the Constitutional Court of the Republic of Croatia, No. U-III-1238/97 of 25 February 1998, under which close family members are considered to be all blood relatives in the straight line, including grandparents.

${ }^{15}$ In 1995, the Ministry of the Economy, Labour and Entrepreneurship expressed the view that the transfer of a day off on the basis of voluntary blood donation to the next calendar year could not be requested. Furthermore, in 2015 the Ministry of Labour and Pension System stated that the ordinance of work cannot prescribe the deadline for obtaining a paid leave for blood donation, as the work ordinance is not specified in the provision of Article 88(6) ZOR as a possible source of regulating rights based on blood donation. Regarding this issue, we quote the opinion of the Ministry of Labour and Pension System of November 26, 2014: "The Labour Act prescribes the right of workers to make a blood donation on a paid day off on the day of the blood donation if in a collective agreement concluded between the workers' council or the labour contract is not otherwise specified. Accordingly, unless the right mentioned is otherwise defined in one of the aforementioned ways, the worker is entitled to one free day for any blood donation." See Interpretation No. 4/31 of 4 April 2014: "According to the Ministry of Health, CLASS: 110-04/13-02/137, URBROJ: 534-08-2/7-14-2. of 10. 1. 2014, voluntary blood donation implies a full blood donation, which, as defined in Article 2 of the Ordinance on special technical requirements for blood preparations (Official Gazette, No. 80/07), is "one dose of blood collected from the blood donor in an anticoagulant solution for processing into blood products for transfusion treatment or further processing." Plasma is, according to Article of the Law on Blood and Blood Preparations (Official Gazette, No. 79/06 and 14/11), defined as the blood component, or part of the blood collected from the donor. Therefore, voluntary plasma donations are not considered voluntary blood donation under Article 31(1)(a)(7) of the Collective Agreement for Civil Servants and Employees."

${ }^{16}$ See Interpretation No. 4/31 of 4 April 2014: "According to the Ministry of Health, CLASS: 110-04/1302/137, URBROJ: 534-08-2/7-14-2. of 10. 1. 2014, voluntary blood donation implies a full blood donation, which, as defined in Article 2 of the Ordinance on special technical requirements for blood preparations (Official Gazette, No. 80/07), defined as "one dose of blood collected from the blood donor in an anticoagulant solution for processing into blood products for transfusion treatment or further processing". Plasma is, according to Article of the Law on Blood and Blood Preparations (Official Gazette, No. 79/06 and 14/11), defined as the blood component, or part of the blood collected from the donor. Therefore, voluntary plasma donations are not considered to be a voluntary blood donation under Article 31(1)(a)(7) of the Collective Agreement for Civil Servants and Employees."
} 
The Ministry of Labour and Pension System gave its opinion on March 27, 2015, since the work ordinance cannot prescribe the deadline for using a paid leave on the basis of blood donation because the work regulations are not specified in Article 86(6) of the Labour Act as a possible source of regulation of rights based on blood donation. ${ }^{17}$

The Ministry of Labour and Pension System gave its opinion on December 19, 2015 according to which: “... during the calendar year the worker is entitled to a paid leave for important personal needs, in particular concerning marriage, childbirth, severe illness or death of a close family member. If ZOR does not define what constitutes a serious illness for the exercise of the right, the opinion is that it is an illness for which there is no cure or other appropriate treatment, due to which a member of a family who is suffering from such an illness needs to be nursed by the worker." The right to a paid leave is provided to a worker during the education or vocational training and specializing for the needs of the workers' council or labour union, but under conditions, duration and compensation provided for by a collective agreement, by an agreement concluded between the workers' council and the employer or the labour ordinance Article 86(4) ZOR).

The paid leave is determined by the law as the exemption from the obligation to work in precisely defined circumstances for which, according to the nature of things, the annual leave or vacation is not used, since the purpose of the annual leave is to let the worker rest from work. Therefore, a worker may not use the vacation for the circumstances for which the law allows him/her the right to a paid leave. Furthermore, a worker who uses a vacation during the course of the circumstances under which he/she is entitled to a paid leave must notify the

\footnotetext{
17 "The Labour Act prescribes the right of workers to be entitled to a paid free day on the day of the donation of blood on the basis of blood donation, unless otherwise agreed by a collective agreement through an agreement concluded between the workers' council or the labour contract. It follows from this provision that some of the aforementioned sources of labour can determine the more favourable right of workers, for example, the right to two paid free days for blood donation. Since the provisions of the Collective Agreement for Public Servants and Employees in Public Services are applied to secondary school employees, we refer to the interpretation of the 141/15 Commission on blood donation: "Every employee has the right to two days of paid leave for each donation of blood during one calendar year. As a rule, these are two days immediately after the donation of blood, and in the case of the inability to use them, in agreement with the employer. If a worker does not work on the day of donating blood, that day is counted as a free day or a paid leave. However, if those two days fall on non-working days, the worker has the right to a paid leave in days when he/she should work and it is necessary to agree on this with the employer." Our opinion is that labour ordinance cannot prescribe a deadline in which these days must be used, because the labour ordinance is not mentioned in the provision of Article 86, paragraph 6 of the Labour Act as a possible source of regulation of rights on the basis of blood donation."
} 
employer without delay and must ask for a paid leave. In that case, the use of the annual leave is interrupted and the paid leave is used, with the agreement with the employer or according to the needs of the job depending on whether the worker will use the unused annual leave, unused for the paid leave, in continuation after the paid leave or in another period of the year. This further means that the paid leave could not be used after a certain period of time from the event or circumstance due to which the worker is exempt from work (e.g. a worker asks to be paid for the leave after 2 months of the death of his/her father), but at the time when the legal circumstances occur, that is, when the events occur (e.g. in the case of a close family member's death the worker is entitled to a paid leave at the time immediately after the death of the family member for the purpose of mourning or preparing the funeral). ${ }^{18}$ Since this right to a leave is prescribed established by law on working days, in days of paid leave the days a worker should be free are not counted on any grounds (weekly rest, free time by redistribution of working hours, holidays, non-working days etc.). On paid leave, the working day spent on a paid leave is recorded for 8 hours. ${ }^{19}$ It is clear from the name of the institute that during the use of the paid leave the worker has the right to salary compensation at the amount stipulated by the employment contract, labour regulations or collective agreement. If not stipulated by the said sources, Article $5 \mathrm{ZOR}$, a worker is entitled to a salary compensation in the amount of the average salary he/she has been paid in the previous three months. If the employer has unjustifiably denied dismissed the worker's right to leave, the worker may seek to exercise his/her rights in accordance with the provisions of Title II.16. of ZOR (exercise of rights and obligations from employment), including the requirement that the court orders the employer to recognize that right. ${ }^{20}$

An employer's wrongful failure to pay leave to a worker represents a serious breach pursuant to Article 228(1)(1) of ZOR. This provision stipulates that a fine of HRK $31,000.00$ to HRK 60,000 will be imposed on the employer as a legal entity for a violation if the employee is not allowed to use a paid leave in the manner and under the conditions prescribed by the ZOR (Article 86 of the ZOR). A fine of 4000.00 to

\footnotetext{
${ }^{18} \mathrm{Cit}$. The right to paid leave during your vacation, available at: http://www.iusinfo.com/DailyContent/Topical.aspx?id=8895.

${ }^{19}$ Thus, according to Interpretation No. 3/31, dated 16 December 2013, which refers to the provision of Article 37(1)(a)(7) of the Collective Agreement for Civil Servants and Employees (Official Gazette, No. 104/13, $150 / 13$, and153/13), whose interpretation can be applied equally to the rights of employees in public services.

${ }^{20}$ See decision of the Supreme Court of RH, Rev 1085/95 from 21. 3. 1996.
} 
6000.00 HRK for this offense shall be imposed on the employer as a natural person and the responsible person of a legal entity. If this offense is committed against a minor, the amount of the fine is doubled.

\section{$5 \quad$ Unpaid leave}

Unpaid leave is the time when a worker is both exempt from labour obligations and the rights and obligations arising from or in connection with the employment relationship, unless otherwise specified (Učur, Zlatović, Moslavac, Malenica, Ćupurdija, 2018: 499; Loje, 2017: 19-20). Unpaid leave is best understood not as a right of the employee but rather as a prerogative of the employer to approve or disapprove (Tintić, 1972: 515). Nevertheless, by virtue of the principle of equality of all workers, it would be advisable to have the circumstances under which a worker can be approved for an unpaid leave regulated by an autonomous act. However, unpaid leave is no longer an ex lege obligation, and so does not limit the worker and the employer with regard to cases for which such leave can be granted. The decision whether to grant the employee's request for unpaid leave ultimately rests solely with the employer. A user of unpaid leave may be any employee employed by the employer. Because Article 87, paragraph 1 of the ZOR explicitly stipulates that the employer may grant a worker an unpaid leave on his/her request, unlike the case with paid leave, the employer's decision to grant the worker's request for unpaid leave is discretionary, not mandatory. The employer's decision whether to grant the worker's request for unpaid leave is not predicated upon any defined set of legal criteria, but instead rests ultimately upon the extent to which the worker's absence in the case of unpaid leave disturbs the normal functioning of work. This decision rests solely with the employer. Article 87 of the ZOR does not state what form the worker's request for unpaid leave should take. Therefore, while the worker's request for the approval of the unpaid leave may be delivered to the employer in writing, the possibility also exists that the worker can make an oral request as well (Božina, 2010: 485).

Exceptionally, according to Article 22(1)(1) of the Law on Maternity and Parental Benefits $^{21}$ the statutory right to a rest in the working relationship is established up until the child turns three years old. Namely, after having exercised the right to maternity and parental leave or the right to half-time work according to the cited law, one of the employed parents is entitled not to work until the child turns three years

${ }^{21}$ Official Gazette, No. 85/08, 110/08, 34/11, 54/13, 152/14 and 59/17. 
old. While exercising this right, other legal rights and obligations that inure to the employed parent are extant, and so, for example, the right to compulsory health insurance and to pension insurance shall be exercised in accordance with the regulations that govern those rights. The employer must submit a copy of the decision on rested employee's employment to the Croatian Health Insurance Institute for registration until the child turns three years of age.

The ZOR does not define the circumstances under which a worker is entitled to unpaid allowance nor does it define the time period for such leave (neither minimum nor maximum). An employee would not be able to make a claim seeking unpaid parttime leave because all unpaid work rights and obligations are dormant during the duration of unpaid leave.

Article 87(2) ZOR explicitly provides that during the period of the approved unpaid leave, employment rights and obligations relative to the employment relationship of the worker to whom the unpaid leave is granted, shall be provided for and settled, unless otherwise provided by law (Moslavac, 2013: 161). ${ }^{22}$

According to the pension insurance regulations, the period of unpaid leave is not included in the pensionable service. Although an employer can dismiss the employee from compulsory and retirement insurance, a worker nonetheless has the right either to continue paying himself/herself contributions for retirement insurance through extended pension insurance or to acquire the status of the insured person in the healthcare insurance system in accordance with health insurance regulations (Frntić, 2017: 427). Thus, the period of unpaid leave for which an employer dismisses a worker from the pension insurance system, and also during which an employee does not pay the contributions concerned through extended insurance, is not included in the period of insurance as pensionable service. Therefore, in the case of unpaid leave, the employment relationship does not cease and is not established again. However, in this case, the exercise of certain rights, such as for example the right to a jubilee award, continues unabated. However, the period in which the worker's employment relationship rests is not counted in the total duration of the employment relationship. Consequently, in the period of continuous employment, both the time spent in the

\footnotetext{
${ }^{22}$ See also the position of the case-law in the judgment: "During a period of employment, the worker is entitled to leave the employment relationship, but the worker's employment is uninterrupted."VSRH, Rev-1671/99, 10. 5. 2001 .
} 
employment relationship with the employer prior to the rested employment and the period spent with the same employer after the rest ends will be counted in calculating pensionable service. ${ }^{23}$ Furthermore, given that the employment relationship continues during the period of unpaid leave, a worker who is in full-time employment cannot enter into additional employment contracts with other employers. During the period of unpaid leave, in accordance with the provisions of the ZOR, either the employer or the employee may terminate the employment contract since the mere act of taking unpaid leave does not, in itself, terminate the employment relationship. In accordance with the provisions of the ZOR and other regulations, a worker's use of the right to unpaid leave does not affect that worker's right to annual leave (Cvitanović, 2014: 184).

On May, 13 2015, the Ministry of Labour and Pension System issued the following opinion regarding the exercise of the right to unpaid leave: "We are of the opinion that a worker who has already concluded a full-time employment contract cannot enter into additional full-time employment contracts. The employer may authorize the worker on his/her request for an unpaid leave, that is to say, rest of employment relationship and the rights and obligations arising out of the employment relationship or in relation to the employment relationship. In the case when the employer grants the worker the right to an unpaid leave, the employment relationship does not terminate with the said employer, but the employment relationship continues to last. In view of the above, a worker who is in full-time employment cannot put his/her employment in rest to enter into an employment contract with another employer. If a worker, without the employer's knowledge, carries out activities from the employer's field of activities without the employer's approval, it constitutes a violation of the prohibition of a worker's competition with the employer, and in that case the employer may demand compensation from the employee. The employer and the employee may possibly conclude an agreement whereby the employer will commit to conclude a new contract about working with the worker after the expiration of the mandate with another employer. Attention is drawn to the fact that when concluding such an agreement, the employer is obliged to take into account the terms of employment established by the law, regulation, collective agreement or employment

\footnotetext{
${ }^{23}$ See the opinion of the Ministry of Labour and Pension System, Class: 110-01/15-01/197; Reg. No: 524-0301-01/4-15-2. from 20. 7. 2015. There are different points of view. Thus, the Supreme Court of the Republic of Croatia in its Decision No. Rev 2985/99 of April 5, 2000 and Rev 1671/99 of 10 May 2001 states that rested periods are counted in the term of employment when it is decisive for the recognition of certain rights, including the right to a jubilee award.
} 
ordinance which are binding." The Ministry of Labour and Pension System gave the following opinion CLASS: 110-01/15-01/42, URBROJ: 524-03-01-01/4-15-2, dated March 9, 2015 regarding the application of the provisions of the ZOR on the right to leave: "The provision of Article 87 of the Labour Act (Official Gazette, No. 93/14) provides for the possibility for the employer to grant to a worker upon his/her request an unpaid leave for which time the rights and obligations arising from employment or in connection with the employment relationship are rested if not otherwise provided by law. During the use of the right to unpaid leave, the worker's employment relationship is not terminated, but the employer can dismiss employees from the pension and health insurance system (regardless of the length of the unpaid leave). If the employer makes a dismissal of compulsory retirement and health insurance, the worker may, during the use of the right to unpaid leave, pay contributions to pension insurance by using an institution of extended retirement pension insurance in accordance with regulations in the field of pension insurance, and the status of the insured person in the health insurance system may be acquired in accordance with regulations in the field of health insurance. Since there is no termination of employment with an employer during the unpaid leave, the worker cannot enter into employment contracts with other employers during that period." The right to unpaid leave of civil servants is more detailed in the Collective Agreement for Civil Servants and Employees. ${ }^{24}$

\section{Conclusion}

Unlike rest pertaining to all workers at a particular employer, leaves are tailored to the individual needs of a particular worker depending on the life circumstances that require the workforce's absence from work. The Croatian Labour Act provides for the right to paid leave and sets forth the procedures for unpaid leave. For the purpose of obtaining employment or rights arising from employment rights, periods of paid leave are regarded as periods of time spent at work. During the unpaid leave the rights and obligations arising from the employment relationship or in connection with the employment relationship shall rest, unless otherwise provided by law. The issue of leave, in particular the right to paid leave, is regulated by the Labour Act and the provisions of collective agreements, labour regulations and employment contracts.

\footnotetext{
${ }^{24}$ Art. 28-33 of the Collective Agreement for Civil Servants and Employees, Official Gazette, No. 112/17.
} 


\section{References}

Belopavlovič, N. et al. (2019), Zakon o delovnih razmerjih s komentarjem (Labour Relations Act with Commentary) (GV Založba, Ljubljana).

Bercusson, B. [ed.] (2002) European labour law and the EU Charter of Fundamental Rights summary edition (Brussels: ETUI).

Božina, A. et al. (2010) Radni odnosi - primjena Zakona o radu (Labour Relations Application of the Labour Act) (Zagreb: RRIF).

Cvitanović, I., Odmori i dopusti (Vacations and Leaves), in Bejaković, P. et al. (2014), Zakon o radu s komentarima i tumačenjima (Labour Act: With Commanders and Interpretations) (Zagreb: TIM Press).

Dedić, S., Gradaščević-Sijerčić, J. (2003) Radno pravo (Labour Law) (Sarajevo: Faculty of Law of the University of Sarajevo and Magistrat).

Frntić, D. F. et al. (2017) Detaljni komentar Zakona o radu (Detailed Commentary on the Labour Act), Second Amended and Amended Edition (Zagreb: Rosip).

Govic, I., Marinkovic Drača, D., Milković, D. (2010) Zakon o radu - komentar, sudska praksa, ogledni primjeri (Labour Act - Commentary, Case Law, Exemplary Examples (Zagreb. TEB).

Jelčić, V., Odmori i dopusti (Vacation and Leave), in CRNKIĆ, T. et al. (2010) Zakon o radu s komentarima i tumačenjima (Labour Act with Commentary and Interpretations) (Zagreb: TIMPress).

Jug, J., Odmori i dopusti u radom pravu (Vacations and Leaves under the Labour Law) in Dika, M. et al. (2010) Ogledi o novom Zakonu o radu - glavna obilježja, ugovori o radu, menadžerski ugovori, plaće, dopusti, otkazi, program zbrinjavanja (Disputes on the New Labour Act - Main Characteristics, Work Contracts, Managerial contracts, salaries, allowances, cancellations, disbursement program) (Zagreb: Official Gazette).

Loje, G. (2017) Neplaćeni dopust (Unpaid leave), Informator, 6467, pp. 19-20.

Löwisch, A. (2003) Labor Law in Europe, Ritsumeikan Law Review, 20, pp.101-115.

Moslavac, B. (2013) Osnove radnog prava za menadžere (Fundamentals of Labour Law) (Virovitica: Senior School for Tourism Management and Informatics in Virovitica).

Swiatkowski, A., Termination of Employment Relationship: The Legal Situation in Poland, https://ec.europa.eu/social/BlobServlet?docId=4633\&langId=en (10. 4. 2019).

Tintić, N. (1972) Radno i socijalno pravo (Labour and Social Law, Book first: Labour Relations (II) (Zagreb: Narodne novine).

Učur, M. Đ. (2010) Slobodni dani s naslova dobrovoljnog darivanja krvi (Free Days of Voluntary Blood Donation), Radno pravo, 5, p. 25-28.

Učur, M.Đ., Zlatović, D., Malenica, I., Ćupurdija, M. (2018) Veliki komentar Zakona o radu (Great comment on Labour Law) (Rijeka: Libertin naklada).

Zlatović, D., Malenica, I. (2016) Novo hrvatsko radno pravo - ogledi iz radnog prava i pravne prakse (New Croatian Labour Law - Essays of employment law and legal practice, the second amended edition) (Rijeka: Libertin naklada). 
LeXonOMICA 